РОЗДІи 2

Maкроекономічні механізми

\title{
The Impact of Socio-economic Factors on the Management of Agro-cooperatives in Local Communities****
}

\author{
Yurty M. Petrushenko ${ }^{i}$, Oksana S. Ponomarenko ${ }^{i i}$, \\ LÍdA BöHMOVÁ iii, Olena V. BYKHOVETs iv, LIUBOV V. KOTIUK ${ }^{v}$
}

\begin{abstract}
The development of entrepreneurial initiatives in the form of agro-cooperatives can be a perspective way for the community to develop through the formation of active civil awareness of the population, to create new jobs, to improve the local infrastructure and to find additional investments. The research aimed at examining structure and factors which influenced cooperatives management in Sumy region. Questionnaires were administered in 5 cooperatives to 19 members. Multiple regression and correlation analyses were performed to identify factors believed to influence cooperatives' management as well as to examine the degree of association between farm-specific and socio-economic variables. To evaluate the importance of cooperatives for its members and management, such a resulted factor, as "receiving a better price as a member of cooperative" was chosen. Results indicate that a significant factor on perception to receive a better price as a member of the agricultural cooperative was age with the effect of the coefficient been about $4.1 \%$. Factors such as gender, education, farm size and ways to resolve conflict situations in the agro-cooperative turned out to be statistically insignificant. The purpose of this research mini-paper is to study certain aspects of the cooperative movement in Ukraine and the Sumy region. The object of research is to identify the extent to which various factors influence the activities of cooperatives. The theoretical and methodological basis of the research reported in the research minipaper were the main provisions of national scientists and development and international experience problems with cooperation, theory, and practice of marketing, personal assessment of the authors. People
\end{abstract}

${ }^{i}$ Yuriy M. Petrushenko, D.Sc. (Economics), Professor, Head of Department of International Economic Relations, Academic and Research Institute of Business Technologies "UAB", Sumy State University;

ii Oksana S. Ponomarenko, Postgraduate student, Specialist of the Department of International Economic Relations of Academic and Research Institute of Business Technologies "UAB", Sumy State University;

${ }^{i i i}$ Lida Böhmová, Student of the Department of Economics and Development, Faculty of Tropical AgriSciences, Czech University of Life Sciences Prague, Czech Republic;

${ }^{\text {iv }}$ Olena V. Bykhovets, Student of the Department of Branches of Agro-Industrial Complex Management, Faculty of Economics and Management, Sumy National Agrarian University;

${ }^{v}$ Liubov V. Kotiuk, Student of the Department of Branches of Agro-Industrial Complex Management, Faculty of Economics and Management, Sumy National Agrarian University.

* This contribution has been supported by the Czech Development Agency through Summer School entitled: "Agri-Cooperatives and Institutions for Rural Development" within the project "Strengthening of capacity building in quality assurance and science at SNAU and SSU".

** This research is realized under the project funded by the Ministry of Education and Science of Ukraine (№ g/r 0117U003935).

(C) Y. M. Petrushenko, O. S. Ponomarenko, L. Böhmová, O. V. Bykhovets, L. Kotiuk, 2019.

https://doi.org/10.21272/mer.2019.85.03 
Yuriy M. Petrushenko, Oksana S. Ponomarenko, Lída Böhmová, Olena V. Bykhovets, Liubov V. Kotiuk. The Impact of Socio-economic Factors on the Management of Agro-cooperatives in Local Communities

with a higher level of education better evaluated the importance of cooperative for the local community. However overall local's vision of the cooperative movement is positive and most of the respondents would like to have more cooperatives in their villages. It was founded, that the lack of information about cooperative movement which resulted in the low interest of low people in joining cooperatives. In light of the above, creating more awareness of the cooperative movement in the local communities could be a way to involve the youth to participate in the cooperative movement.

Keywords: socio-economic development, local communities, agricultural cooperatives, management, regional development.

УДК $330.33 / 332.1: 338$

JEL Codes: D79, O18, R31

Introduction. At the current stage of State development, the decentralization reform is a key focus of the Ukrainian Government. The main goal of the reform is to form capable local communities. The urgent issue is to ensure the financial capacity of the newly created territorial communities. One of the main factors in ensuring its capacity is to develop a business environment, in particular through the establishment of agro-cooperatives. This could help to create a favorable investment climate in the region, create new jobs, increase salaries and payments to the local budgets.

Cooperation is a system of cooperative organizations created to satisfy the economic, social and other needs of their members [1]. The members are investors as well as consumers. Their main aim is to help their members with their needs, unlike other business organizations that are focused solely on gaining profit.

It is stated, that cooperatives are considered to be an inherent part of the market economic system and democratic society [2]. Another reason for the importance of small farmer organizations is better access to markets, lower transaction costs, gaining necessary market information. These reasons are especially important in countries that have a high number of big agribusinesses and foreign investors [3].

In the words of Olexandr Pavlenko, the executive director of agricultural cooperative Sumy Orchards: "before the crash of the Soviet Union, on the territory of Ukrainian republic, the system of efficiently working cooperatives was created. But another wave of privatization in independent Ukraine broke this system down and divided property between people, who did not know what to do with it. At this same time, first agro-holdings started to appear and even the law about cooperatives could not help the villagers to use their land in the right way, because they already had contracts with agro-holdings".

The restructuring of former Soviet kolkhozes resulted in different forms of cooperative organizations. Even after more than 20 years of de-collectivization, the internal structure of cooperatives is not well known. The cooperation was a well-known practice in Ukrainian territories well before the collectivization that took place in Soviet times. The totalitarian regime during the time of Stalin's reign caused a negative perception of a cooperative between agricultural producers as well as consumers [2]. That is why the approach to agricultural cooperatives in the countries that experienced the forced collectivization is unfavorable.

Problem statement. According to the Ministry of Agrarian Policy data, there were 1125 registered cooperatives in Ukraine at the end of 2017. Only 610 were working while others existed only on paper. In the studied Sumy region, there are 47 - registered co-ops of which 33 are not-working ones [4].

Researchers note the already proven advantages of cooperative action which is 'voluntary action by a group to pursue shared objectives - for technology adoption and to ensure that resource use is efficient, equitable and sustainable. It is shown, that agricultural cooperatives 
can be a good opportunity for small farmers and peasants to participate more effectively in the market. Also, there is evidence that collective action can help smallholders to reduce barriers to entering markets by allowing them to compete with large farmers and agricultural enterprises [3].

Agro-holdings currently cultivate a great number of hectares in Ukraine and the number is growing. Despite all that, this process is slower than before, because agro-holdings are incorporating more intensive ways of increasing their production. To fight this agricultural structure, cooperatives help with educational programs for farmers, foreign grants, governmental help, credit programs and other kinds of monetary support for co-operatives and their members that can be used just for the entering different innovations into the holdings of small farmers [5].

Over the years economists expressed their criticism over cooperative action. They concluded some of the main arguments - unclear property rights, high agency costs, uncertain technical efficiency, etc. It is noted, that members of cooperatives do not control the management, investments for development are short-term and accumulated investments are lower than economic optimum, etc. [6]. Crucial point is to state when cooperatives make sense. "When poverty reduction is the overriding goal, facilitating access to markets may not be the best way forward" [3].

Nevertheless, many cooperative organizations work well for their members and contribute to the local socio-economic development. That is why the study of the current situation of the functioning of management in agrarian cooperatives is extremely relevant. This will improve the efficiency of the operation of these cooperatives. Cooperatives can appear only when cooperative members express their willingness to cooperate and start the organizational procedures. That is why it is crucial to study the internal management of cooperatives.

Purpose. Therefore, the main aim of this research is to examine common structures and management of cooperatives in the Sumy region. The other objectives are to describe profit groups of small farmers - particularly Sumy Orchards cooperative, to study internal management and to identify socially demographic factors that influence on cooperative members.

Results of the research. 5 cooperatives in the Sumy region (milk cooperatives in Chernecha Sloboda, goat milk in Vyry, grain cooperative in Tovste, milk and information services cooperatives in Shevchenkovo, apple production cooperative - Shpetivka) were selected into the sample for the research.

The primary dates were collected on the site from the managers and members of cooperatives in Ukraine. The interviews were conducted with the aim to obtain data on the current situation of cooperatives and to study the processes of internal management, studying the expectations of a cooperative member from co-production. Visits to the cooperatives were conducted for 4 days, the time of a survey of one respondent was about half an hour after the completion of the survey photographic fixation was conducted.

Data sources, sample size and sampling technique, data analysis

Primary data was acquired through the administration of questionnaires that focused on the management and internal governance of cooperatives. The questionnaire was compiled in English and Ukrainian languages, the survey was conducted in Ukrainian. The questionnaire was divided into two parts -5 questions solely for the manager and 9 questions for managers and members. The method selected for the collection of primary data was a personal interview 
Yuriy M. Petrushenko, Oksana S. Ponomarenko, Lída Böhmová, Olena V. Bykhovets, Liubov V. Kotiuk. The Impact of Socio-economic Factors on the Management of Agro-cooperatives in Local Communities

for managers and members. Convenient sampling was applied to select in total 19 members including managers of the five cooperatives.

The first part of the results uses basic descriptive in order to better understand the internal situation of Ukrainian cooperatives. The main variables used for the description of internal management practices are given in the questionnaire.

We also applied multiple regression analysis to assess factors, which influence farmers understanding of internal situation of Ukrainian including managers of the five cooperatives. Also, correlation analysis was performed to identify the degree of relationship farm specific characteristics and socio-economic factors believe to influence farmers' perception about the price they receive for their products as cooperative members. Mathematically, the regression model can be formulated as follows:

$$
Y=\beta_{0}+\beta_{1} x_{1}+\ldots+\beta_{q} x_{q}+\varepsilon
$$

$\mathrm{Y}$ - dependent variable; $\mathrm{X}_{q}$ - independent variables; $\beta_{q}$ - coefficient of regression; $\varepsilon-$ random error.

Table 1

The variables for multiple regression analysis

\begin{tabular}{|c|l|}
\hline Variables & Interpretation \\
\hline $\mathrm{X} 1$ & age in years \\
\hline $\mathrm{X} 2$ & gender \\
\hline $\mathrm{X} 3$ & education \\
\hline $\mathrm{X} 4$ & farm size \\
\hline $\mathrm{X} 5$ & conflict management \\
\hline $\mathrm{Y}$ & better price as a cooperative member \\
\hline
\end{tabular}

Management and member characteristics of cooperatives

Figure 1 indicates that out of the total 19 members, 15 representing $79 \%$ were males while 4 representing $21 \%$ were females. This has an implication that perhaps females have less interest in cooperatives or are most often excluded from social institutions such as cooperatives. However, this may also be the impact of our sample.

This result is similar to the study conducted by Kustrich L. O. and Zaporozhets T. V. [7] in Ukraine who also found that most cooperative members comprise males instead of females.

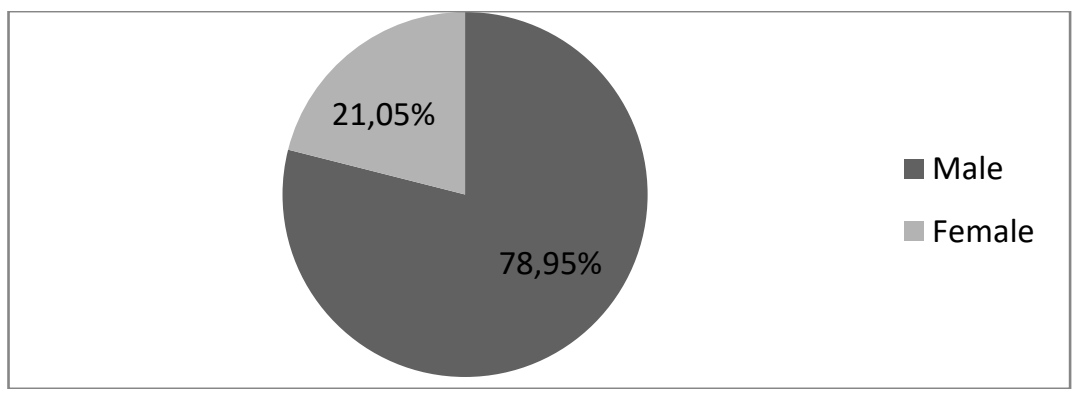

Figure 1. The age structure of cooperative members 
The same observations we found in the research made by FAO [8]. Statistics prove that only $43 \%$ of females participate in agribusiness. The gap between women and men in agriculture is especially visible in the access to resources and services. FAO statistics show that labour productivity among genders is due to the different use of factors of production. FAO's study shows that the increase of farm yields by 20-30\% could be reached if women obtained the same access to productive resources as men.

Figure 2 shows the initial structure of participants in cooperatives. As we can see people aged 50 to 60 and 40 to 50 are predominant. On one hand, this indicates that some people experience some kind of knowledge of the cooperatives, and on the other, it shows the problem of migration of young people from rural areas and their disinterestedness to work and live in villages.

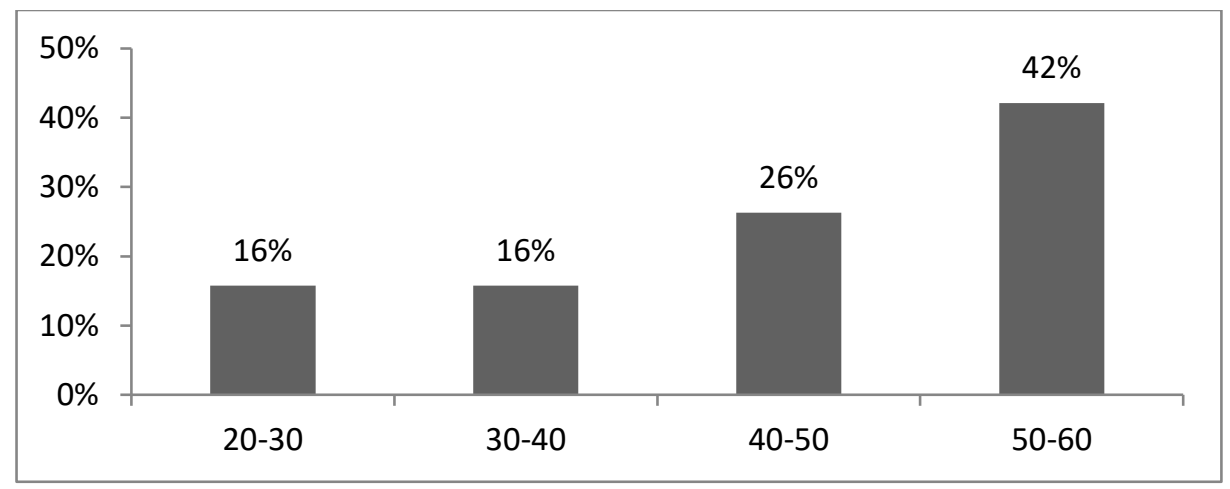

Figure 2. The age structure of cooperative members

Figure 3 shows the main ways of solving conflicts by members of the cooperative. As can be seen from the study, most cooperatives come to a common solution through discussion.

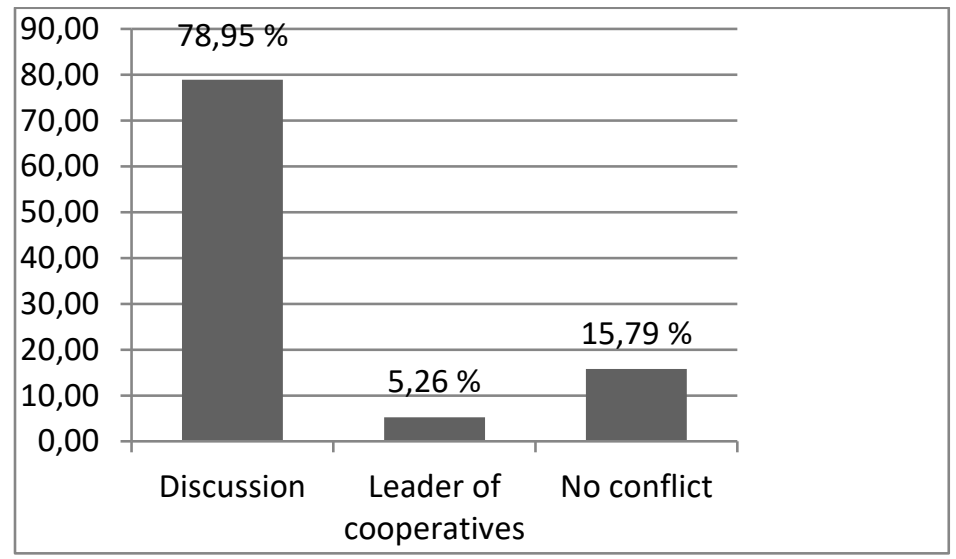

Figure 3. The structure of Conflict management

Figure 4 shows the results of the Likert Scale variables. As a result of the study, the distribution of expectations of cooperative members regarding the results of joint activities 
Yuriy M. Petrushenko, Oksana S. Ponomarenko, Lída Böhmová, Olena V. Bykhovets, Liubov V. Kotiuk. The Impact of Socio-economic Factors on the Management of Agro-cooperatives in Local Communities

was obtained. It is established that the majority of participants $42 \%$ and $47 \%$ respectively, absolutely agree that the cooperation will allow them to establish a better price for their products and enter new markets.

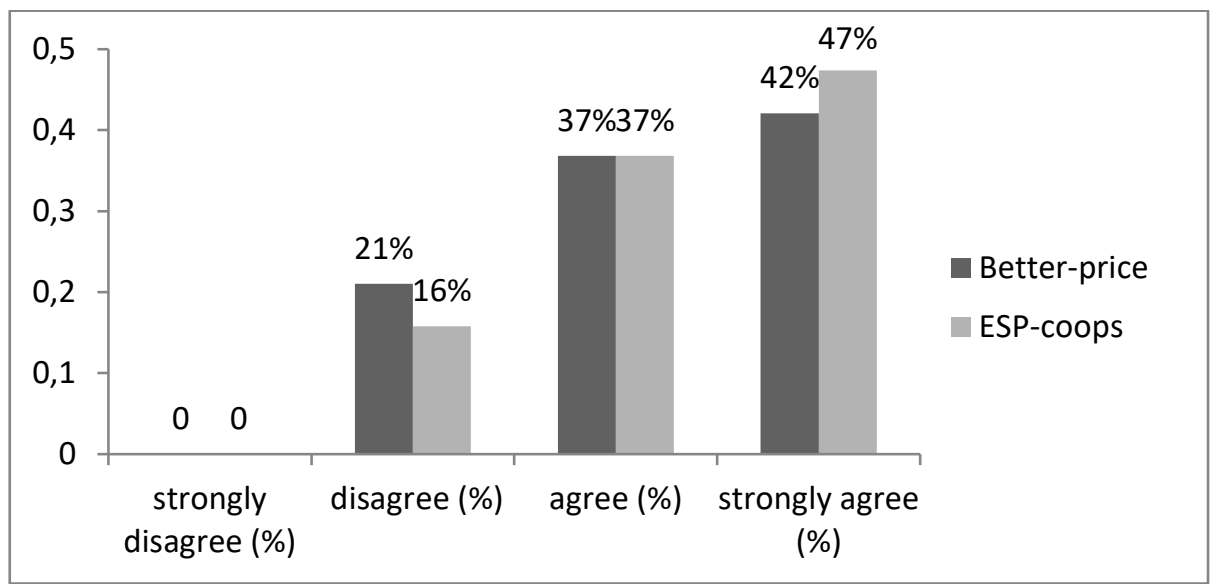

Figure 4. Perception of pricing of products and expand new markets

For-profit group of small farmers - Sumy Orchards cooperative

In our research group, we focused on internal management of Sumy Orchards cooperative. Its main activity is the production and processing of different varieties of apples (French, German, and Japanese). The other direction is a cultivation of berry bushes. Currently, they have uncultivated 30 ha of land which they plan to use for grain production. Sumy Orchards started to move towards organic production and are working towards official certification.

This enterprise consists of 23 members and is located in Sumy region. The average age of members and workers is between 35-50 years, they shared with seedlings and equipment. The major reason for creating the Sumy Orchard's cooperative was to improve the profit from apple production. They registered as an official cooperative in 2013 and had no problems with the registration process. Their primary cooperative services to its members are processing products and achieving the market.

Cooperatives are operated democratically through electing the board of members. However, Sumy Orchard's cooperative has 3 permanent board members who are also the founders (Pavlenko Dmitry Alexandrovich, Pavlenko Alexander Ivanovich, and Lysyancky Nikolay Vladimirovich) and they do not elect any new ones. There are admission fees for cooperative members and the particular sum is decided by the board. They accept new cooperative members and the main requirement of acceptance is to have a minimum of 1 ha of land.

When it comes to government subsidies the cooperative received them twice, once in 2013 and once in 2015. These loans are expected to be given back once the cooperative is making big enough revenue. So far, they have not received any grants from international donors, but they get support from an NGO and received 2 credits from a bank.

Our goal was to identify socially demographic factors that positively influence the farmers' perception to receive a better price as a member of the agricultural cooperative. Factors such as gender, education, farm size and ways to resolve conflict situations in the agro-cooperative turned out to be statistically insignificant. A significant factor was the age of a member of the 
Ю. М. Петруиенко, О. С. Пономаренко, Л. Бемова, О. В. Биховець, Л. В. Котюк.

Вплив соціально-економічних факторів

на управління агрокооперативами в місцевих громадах

cooperative, which indicates that people with sufficient life and professional experience understand the benefits of joining an agro-cooperative.

Table 2

Impact of demographic and social factors on farmers' perception for the price received from cooperatives as members

\begin{tabular}{|l|c|c|c|c|}
\hline \multicolumn{1}{|c|}{ Variables } & Coefficient & Standard error & t-statistics & P-Value \\
\hline constant & 0.362551 & 0.855622 & 0.423728 & 0.678 \\
\hline age & 0.040813 & 0.015228 & 2.680092 & $\mathbf{0 . 0 1 9} * *$ \\
\hline gender & -0.1162 & 0.389709 & -0.29817 & 0.770 \\
\hline education & 0.258501 & 0.198957 & 1.299281 & 0.216 \\
\hline farm size & 0.018017 & 0.028681 & 0.628205 & 0.54074918 \\
\hline $\begin{array}{l}\text { conflict } \\
\text { management }\end{array}$ & 0.25274 & 0.200376 & 1.261325 & 0.229356409 \\
\hline
\end{tabular}

** refers to significance level at $5 \%$

Results of the regression analysis indicate overall, that the explanatory variables explain about $53 \%$ of the variations in the explained variable. Among the socio-economic variables, only age was statistically significant at $5 \%$ with the effect of the coefficient been about $4.1 \%$. This implies that a unit change in the explained variable will lead to 0.041 in the explanatory variable age.

Table 3

Correlation analysis

\begin{tabular}{|l|c|c|c|c|c|c|}
\hline & Education & $\begin{array}{c}\text { Farm } \\
\text { size }\end{array}$ & $\begin{array}{c}\text { Better- } \\
\text { price }\end{array}$ & $\begin{array}{c}\text { Conflict } \\
\text { manage- } \\
\text { ment }\end{array}$ & $\begin{array}{c}\text { Agreement } \\
\text { with } \\
\text { management }\end{array}$ & $\begin{array}{c}\text { Expansion of } \\
\text { sales by } \\
\text { cooperatives }\end{array}$ \\
\hline Education & 1 & & & & & \\
\hline Farm size & 0.108 & 1 & & & & \\
\hline Better-price & 0.234 & 0.394 & 1 & & & \\
\hline $\begin{array}{l}\text { Conflict } \\
\text { management }\end{array}$ & 0.040 & 0.191 & 0.327 & 1 & & \\
\hline $\begin{array}{l}\text { Agreement } \\
\text { with } \\
\text { management }\end{array}$ & 0.286 & 0.123 & -0.241 & -0.061 & 1 & \\
\hline $\begin{array}{l}\text { Expansion of } \\
\text { sales by } \\
\text { cooperatives }\end{array}$ & -0.021 & 0.296 & 0.024 & -0.021 & 0.266 & 1 \\
\hline
\end{tabular}

From Table 3, we observed a positive but weak association between conflict management and better price received by cooperative members. Similarly, there was a positive relationship between farm size and expansion of sales points by cooperatives even though the effect is weak (0.296). Additionally, education and agreement with management decision saw a positive relationship but a weak effect.

Conclusions and prospects of further research. Our goal was to identify socially demographic factors that positively influence the farmers' perception to receive a better price 
Yuriy M. Petrushenko, Oksana S. Ponomarenko, Lída Böhmová, Olena V. Bykhovets, Liubov V. Kotiuk. The Impact of Socio-economic Factors on the Management of Agro-cooperatives in Local Communities

as a member of cooperative and so it also can positively influence the decision to join the agricultural cooperative. Factors such as gender, education, farm size and ways to resolve conflict situations in the agro-cooperative turned out to be statistically insignificant. A significant factor was the age of a member of the cooperative, which indicates that people with sufficient life and professional experience understand the benefits of joining an agrocooperative.

The first part of the research shows a clear structure of members in cooperatives and describes one typology of the cooperative. From asked respondents it is evident men predominate in the structure of participants in agricultural cooperatives. People aged 40 to 60 are the majority as well. This result could serve as further research for further study on the migration of young people from rural areas and their interest to work in agriculture. The research established that the majority of participants (42\% and $47 \%$ respectively), absolutely agree that participation in cooperation will allow them to get a better price for their products and enter new markets. Among the socio-economic variables, only age was statistically significant at $5 \%$ with the effect of the coefficient been about $4.1 \%$. This implies that a unit change in the explained variable will lead to 0.041 in the explanatory variable age. We observed a positive but not strong association between conflict management and better price received by cooperative members. Likewise, there was a positive relationship between farm size and expansion of sales points by cooperatives.

\section{References}

1. Pro kooperatsiiu: Zakon Ukrainy [Law of Ukraine about Cooperation: Information]. \# 1087-IV from 10.07.2003. Retrieved from http://zakon5.rada.gov.ua/laws/show/1087-15.

2. Zinovchuk, V. (2007). Supporting agrobusiness in Ukraine: Cooperatives and beyond. The State University of Agriculture and Ecology, Ukraine. Retrieved from http://vadyba.asu.lt/9/73.pdf.

3. Markelova, H., Meizen-Dick, R., Hellin, J., Dohrn, S. (2009). Collective action for smallholder access. Food Policy, 34, 1-7.

4. Ministerstvo ahrarnoi polityky ta prodovolstva Ukrainy [Ministry of agrarian policy and food of Ukraine] (2018). Retrieved from http://minagro.gov.ua.

5. Kooperativy - svetloye budushcheye dlya fermerov [Cooperatives - a bright future for farmers] (2017). Retrieved from http://landlord.ua/operatsiya-kooperatsiya.

6. Nilsson, J. (2001). Organisational principles for co-operative firms. Scandinavian Journal of Management, 17, 329-356.

7. Kustrich, L. O. and Zaporozhets, T. V. (2010). Analiz trudovoho potentsialu pidpryiemstva yak vazhlyvoho etapu upravlinnia nym [Analysis of the labor potential of the company as an important stage in managing it]. Collection of student scientific works of Uman National University of Horticulture.

8. Zhinky v silskomu hospodarstvi: Usunennia hendernoho rozryvu $\mathrm{v}$ interesakh rozvytku [Women in Agriculture: Closing the gender gap for development] (2010). Prodovolstvennaya selskokhozyaystvennaya $\quad$ organizatsiya $\quad$ OON. $\quad$ Retrieved from http://www.fao.org/publications/sofa/2010-11/ru/.

Manuscript received 02 September 2019

Влияние социально-экономических факторов на управление агрокооперативами в местных общинах

ЮРИй НИКОЛАЕВИч ПЕТРУШЕНКО*, ОКСАНА СЕРГеЕвнА ПоНОМАРенко* ${ }^{*}$, 


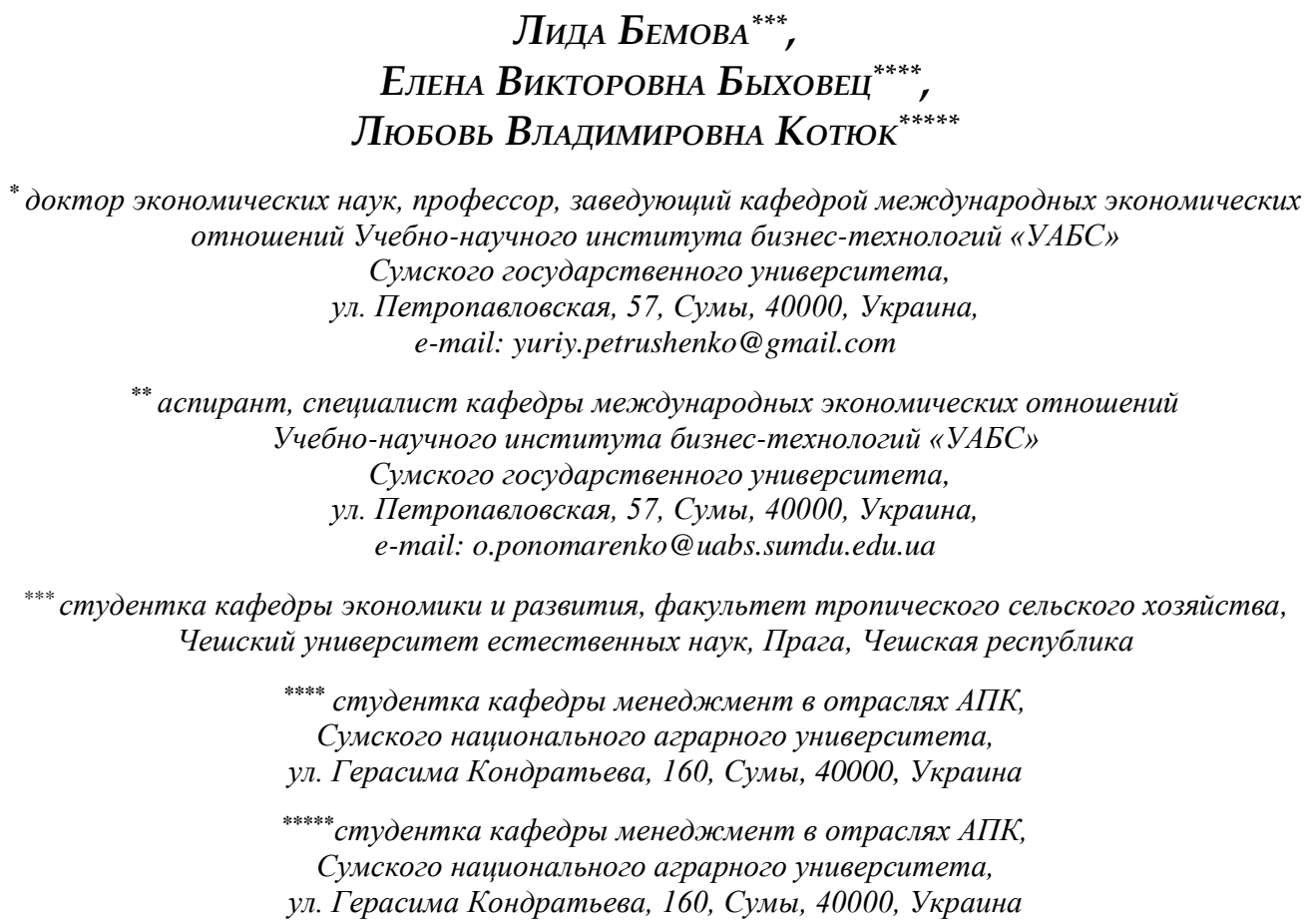

Развитие предпринимательских инициатив, в формате агрокооперативов, может стать перспективным путем развития местных общин через формирование активной гражданской позиции населения, создание новых рабочих мест, улучшение местной инфраструктуры и поиска дополнительных инвестиций. Данное исследование направлено на изучение структуры и факторов, влияющих на управление кооперативами в Сумской области. Анкетирование проводилось в 5 кооперативах среди 19 членов. Было проведено многофакторный регрессионный и корреляционный анализ для выявления факторов, которые могут влиять на управление кооперативами, а также для изучения степени связи между фермерским менеджментом и социально-экономическими факторами. Чтобы оценить важность кооперативов для его членов и менеджмента, был выбран такой результирующий фактор, как «получение лучшей цены в качестве члена кооператива». Результаты показывают, что наиболее весомым фактором, обеспечивающим ожидания того, что участие в агрокооперативе обеспечит лучшую цену за продукцию, был возраст респондента. Вес этого фактора составляет около 4,1%. Такие факторы, как пол, образование, размер фермерских хозяйств и пути решения конфликтных ситуаций в агрокооперативе, оказались статистически незначимыми. Целью данного исследовательского мини-доклада является изучение отдельных аспектов кооперативного движения в Украине и Сумской области. Объектом исследования является определение степени влияния различных факторов на деятельность кооперативов. В теоретико-методологическую основу исследования, были положены работы отечественных ученых и международный опыт проблем кооперации, а также теория и практики маркетинга, и личные оценки авторов. Люди с более высоким уровнем образования выше оценили важность кооперативов для местных общин. Однако в целом видение кооперативного движения является позитивным, и большинство респондентов хотели бы иметь больше кооперативов в своих селах. Было установлено, что отсутствие информации о кооперативном движении привело к низкой заинтересованности местных жителей к вступлению в кооперативы. В свете вышесказанного, повышение осведомленности о кооперативном движении в местных общинах может стать способом вовлечения молодежи в кооперативное движение. 
Yuriy M. Petrushenko, Oksana S. Ponomarenko, Lída Böhmová, Olena V. Bykhovets, Liubov V. Kotiuk. The Impact of Socio-economic Factors on the Management of Agro-cooperatives in Local Communities

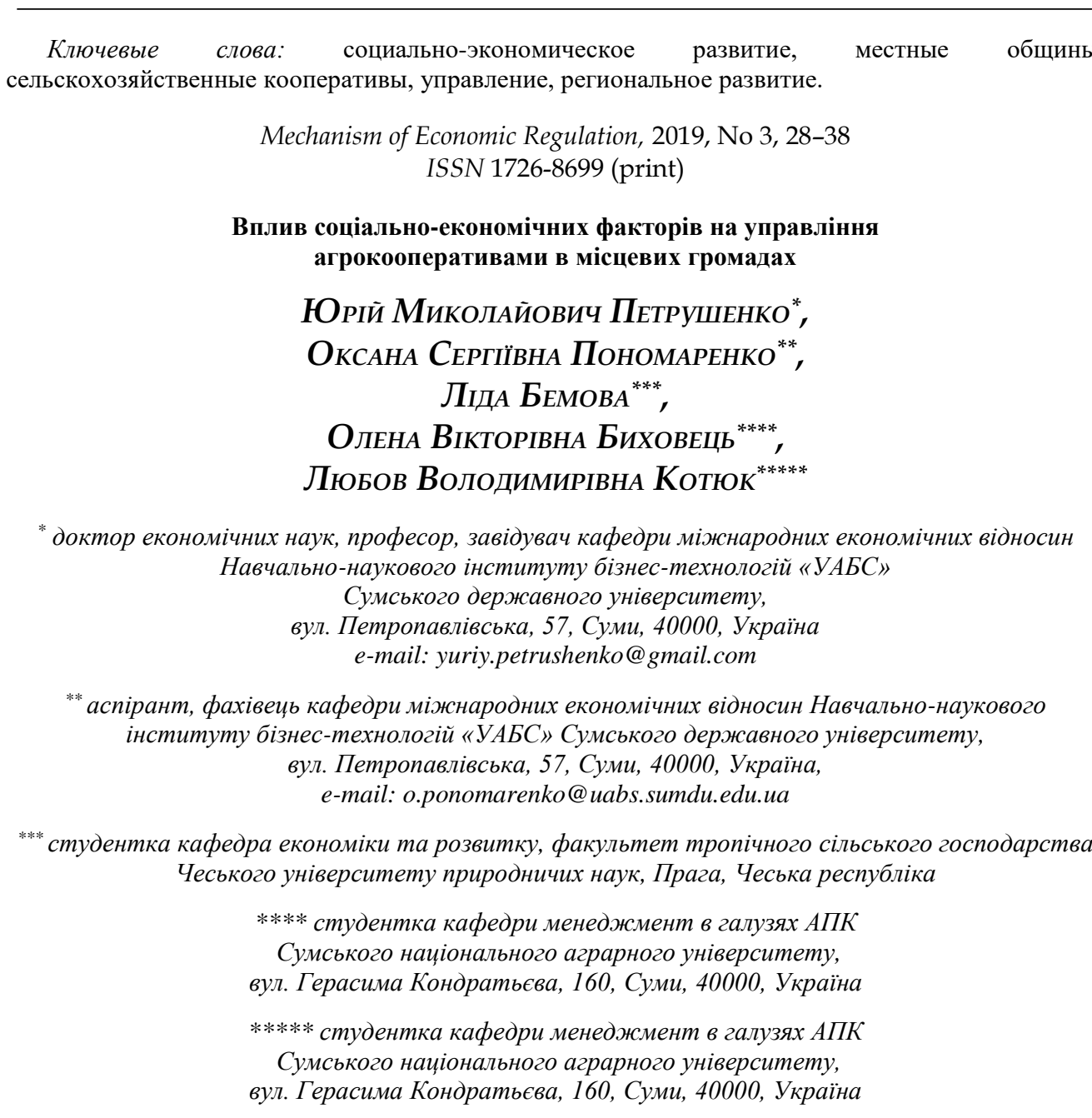

Розвиток підприємницьких ініціатив, у форматі агрокооперативів, може стати перспективним шляхом розвитку громади через формування активної громадянської позиції населення, створення нових робочих місць, покращення місцевої інфраструктури та пошуку додаткових інвестицій. Дане дослідження спрямоване на вивчення структури та факторів, що мають вплив на управління кооперативами у Сумській області. Анкетування проводилось у 5 кооперативах серед 19 членів. Було проведено батагофакторний регресійний та кореляційний аналіз для виявлення факторів, які можуть впливати на управління кооперативами, а також для вивчення ступеня зв'язку між фермерським менеджментом та соціально-економічними факторами. Щоб оцінити важливість кооперативів для його членів і менеджменту, був обраний такий результуючий фактор, як «отримання кращої ціни в якості члена кооперативу». Результати показують, що найбільш вагомим фактором, що забезпечує очікування того, що участь в агрокооперативі забезпечить кращу ціну за продукцію, був вік респондента. Вага цього фактора становить близько $4,1 \%$. Такі фактори, як стать, освіта, розмір фермерських господарств та шляхи вирішення конфліктних ситуацій в агрокооперативі, виявились статистично незначущими. Метою даної дослідницької міні-доповіді $є$ вивчення окремих аспектів кооперативного руху в Україні та Сумській області. Об'єктом дослідження є визначення ступеня впливу різних факторів на 
діяльність кооперативів. В теоретико-методологічну основу дослідження, викладеного в дослідницькому міні-документі, були покладено положення вітчизняних вчених та міжнародний досвід проблем кооперації, а також теорія та практики маркетингу та особисті оцінки авторів. Однак в цілому, бачення кооперативного руху є позитивним, і більшість респондентів хотіли б мати більше кооперативів в своїх селах. Було встановлено, що відсутність інформації про кооперативний рух призвело до низької зацікавленості місцевих жителів до вступу в кооперативи. У світлі вищесказаного, підвищення обізнаності про кооперативний рух в місцевих громадах може стати способом залучення молоді до кооперативного руху.

Ключові слова: соціально-економічний розвиток, місцеві громади, сільськогосподарські кооперативи, управління, регіональний розвиток.

JEL Codes: D79, O18, R31

Tables: 3; Figures: 4; Formula: 1; References: 8

Language of the article: English

Jimepamypa

1. Про кооперацุiю: Закон України від 10.07.2003 № 1087-IV [Електронний ресурс]. - Режим доступу : http://zakon5.rada.gov.ua/laws/show/1087-15.

2. Zinovchuk, V. Supporting agrobusiness in Ukraine: Cooperatives and beyond [Electronic resource] / V. Zinovchuk // The State University of Agriculture and Ecology, Ukraine. - 2007. - Accessed mode : http://vadyba.asu.lt/9/73.pdf.

3. Markelova, H. Collective action for smallholder access / H. Markelova, R. Meizen-Dick, J. Hellin, S. Dohrn // Food Policy. - 2009. - № 34. - P. 1-7.

4. Міністерство аграрної політики та продовольства України [Електронний ресурс]. - 2018. Режим доступу : http://minagro.gov.ua.

5. Кооперативи - світле майбутнє для фермерів [Електронний ресурс]. - Landlord, 2017. Режим доступу : http://landlord.ua/operatsiya-kooperatsiya.

6. Nilsson, J. Organisational principles for co-operative firms / J. Nilsson // Scandinavian Journal of Management. - 2001. - Vol. 17. - P. 329-356.

7. Кустріч, Л. О. Аналіз трудового потенціалу підприємства як важливого етапу управління ним / Л. О. Кустріч, Т. В. Запорожец // Збірник студентських наукових робіт Уманського національного університету садівництва. - 2010. - С. 285.

8. Продовольча сільськогосподарська організація Об'єднаних націй [Електронний ресурс]. Жінки в сільському господарстві: Усунення гендерного розриву в інтересах розвитку. - 2010. - Режим доступу : http://www.fao.org/publications/sofa/2010-11/ru/. 